\title{
Sleep bruxism, painful temporomandibular disorders, and self reported headache in a sample population of adolescents
}

Giovana Fernandes, DDS, MSc'; Ana L Franco, DDS, MSc'; Fernanda Bonafé, SS DDS ${ }^{3}$;

Daniela Gonçalves, AG DDS, $\mathrm{PhD}^{4}$; Cinara Camparis, M DDS, $P h D^{5}$

${ }^{1,2,3}$ Graduated Student, ${ }^{4}$ Assistant Professor, ${ }^{5}$ Associated Professor, Araraquara Dental School, UNESP Universidade Estadual Paulista, Department of Dental Materials and Prosthodontics, Araraquara, SP, Brazil

Fernandes G, Franco AL, Bonafé F, Gonçalves D, Camparis C. Sleep bruxism, painful temporomandibular disorders, and self reported headache in a sample population of adolescents. Headache Medicine. 2012;3(4):220-2

\section{INTRODUCTION}

Headache $(\mathrm{HA})$ is the most common manifestation of pain in adolescence. Its prevalence rate is $51 \%$ in adolescents and it is being perceived as a significant health problem by pediatricians and parents. (1) Moreover, HA is a frequent cause of disability, affecting the adolescence life. (2) Investigations of risk factors for HA are essential to prevention and treat this neurological disorder to minimize its impact on quality of life.

Among the risk factors for $\mathrm{HA}$, temporomandibular disorder (TMD) and sleep bruxism (SB) have been considered. HA are often observed in adolescents diagnosed with $\mathrm{TMD}^{(3)}$ and $\mathrm{SB}$ adolescents frequently reported HA. ${ }^{(6)}$

However, there is a lack of population-based studies and a multiple association among SB, HA and TMD are not explored. Based on these statements, the aim of the present study is to investigate a possible association among these three entities.

\section{MATERIAL AND METHOD}

The sample consisted of public school students, 11 to 16 years aged, from Araraquara - SP, Brazil. Overall, 24 public schools were visited and 3,117 adolescents 
were invited to participate. This study received full approval of the Research Ethic Committee of Faculdade de Odontologia de Araraquara, UNESP - Universidade Estadual Paulista (process \# 70/10).

For TMD pain characterization and HA assessment, data were obtained from Research Diagnostic Criteria for Temporomandibular Disorders (RDC/TMD) Axis I (intraexaminer kappa values range from 0.529 to 0.884 ), in addition to questions \#3 (Have you had pain in the face, jaw, temple, in front of the ear or in your ear in the past month?), \#4 (How many time did your facial pain begin for the first time?), \# 14 (Have you ever had your jaw lock or catch so that it won't open all the way) and \# 18 (During the last six months have you had a problem with headaches or migraines?) ( $k a p p a=0.688)$ of Axis II history questionnaire. ${ }^{(5)}$ SB was diagnosed according to validated $^{(6)}$ clinical criteria proposed by the American Academy of Sleep Medicine. ${ }^{(7)}$ Data were analyzed by chi-square and Odds Ratio (OR) test with a 95\% confidence interval $(\mathrm{Cl})$ and the significance level adopted was 0.05 .

\section{RESULT}

The sample consisted of 1,122 adolescents $(54.7 \%$ girls), with average age of 12.7 years. It was found association among SB, painful TMD and headache selfreport $(p<0.0001)$. The SB increased the risk for painful $\operatorname{TMD}(\mathrm{OR}=2.5 ; 95 \% \mathrm{Cl}=1.91$-3.39) (Table 1).

\begin{tabular}{|c|c|c|c|c|c|}
\hline & & \multicolumn{3}{|c|}{ Sleep Bruxism } & \\
\hline & & Absence & Presence & Total & \\
\hline & & $\begin{array}{c}n \\
(\%)\end{array}$ & $\begin{array}{r}n \\
(\%)\end{array}$ & $\begin{array}{r}n \\
(\%)\end{array}$ & OR $95 \% \mathrm{Cl}$ \\
\hline \multirow{2}{*}{$\begin{array}{l}\text { Painful } \\
\text { TMD } \\
\text { diagnosis }\end{array}$} & Absence & $\begin{array}{r}653 \\
(78.2)\end{array}$ & $\begin{array}{r}182 \\
(21.8)\end{array}$ & $\begin{array}{r}835 \\
(100.0)\end{array}$ & Reference \\
\hline & Presence & $\begin{array}{r}168 \\
(58.5) \\
\end{array}$ & $\begin{array}{r}119 \\
(41.5) \\
\end{array}$ & $\begin{array}{r}287 \\
(100.0) \\
\end{array}$ & $\begin{array}{c}2.5(1.91-3.39) \\
p<0.0001\end{array}$ \\
\hline Total & & $\begin{array}{r}821 \\
(73.2)\end{array}$ & $\begin{array}{r}301 \\
(26.8)\end{array}$ & $\begin{array}{r}1122 \\
(100.0)\end{array}$ & \\
\hline
\end{tabular}

Similarly, painful TMD and SB increased the risk for headache self-report. The magnitude of association was higher for painful TMD $(\mathrm{OR}=5.1 ; 95 \% \mathrm{Cl}=3.76-6.83)$, followed by SB (OR=1.7; 95\% Cl=1.30-2.21) (Tables 2 and 3).

When the sample was stratified by the presence of $S B$ and painful TMD, the presence of SB only did not
Table 2 - Association between painful temporomandibular disorders (TMD) diagnosis and headache self-report

\begin{tabular}{|c|c|c|c|c|c|}
\hline & & \multicolumn{3}{|c|}{ Painful TMD } & \\
\hline & & Absence & Presence & Total & \\
\hline & & $\begin{array}{c}n \\
(\%)\end{array}$ & $\begin{array}{c}n \\
(\%)\end{array}$ & $\begin{array}{r}n \\
(\%)\end{array}$ & OR $95 \% \mathrm{Cl}$ \\
\hline \multirow{2}{*}{$\begin{array}{l}\text { Headache } \\
\text { Self } \\
\text { Reported }\end{array}$} & Absence & $\begin{array}{r}536 \\
(87.7)\end{array}$ & $\begin{array}{r}75 \\
(12.3)\end{array}$ & $\begin{array}{c}611 \\
(100.0)\end{array}$ & Reference \\
\hline & Presence & $\begin{array}{r}299 \\
(58.5) \\
\end{array}$ & $\begin{array}{r}212 \\
(41.5) \\
\end{array}$ & $\begin{array}{r}511 \\
(100.0) \\
\end{array}$ & $\begin{array}{c}5.1(3.76-6.83) \\
p<0.0001\end{array}$ \\
\hline Total & & $\begin{array}{r}835 \\
(74.4)\end{array}$ & $\begin{array}{r}287 \\
(25.6)\end{array}$ & $\begin{array}{r}1122 \\
(100.0)\end{array}$ & \\
\hline
\end{tabular}

Table 3 - Association between sleep bruxism and headache self-report

\begin{tabular}{|c|c|c|c|c|c|}
\hline & & \multicolumn{3}{|c|}{ Sleep Bruxism } & \\
\hline & & Absence & Presence & Total & \\
\hline & & $\begin{array}{c}n \\
(\%)\end{array}$ & $\begin{array}{c}n \\
(\%)\end{array}$ & $\begin{array}{c}n \\
(\%)\end{array}$ & OR 95\% Cl \\
\hline \multirow{2}{*}{$\begin{array}{l}\text { Headache } \\
\text { Self } \\
\text { Reported }\end{array}$} & Absence & $\begin{array}{r}476 \\
(77.9)\end{array}$ & $\begin{array}{r}135 \\
(22.1)\end{array}$ & $\begin{array}{r}611 \\
(100.0)\end{array}$ & Reference \\
\hline & Presence & $\begin{array}{r}345 \\
(67.5)\end{array}$ & $\begin{array}{r}166 \\
(32.5)\end{array}$ & $\begin{array}{r}511 \\
(100.0) \\
\end{array}$ & 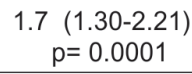 \\
\hline Total & & $\begin{array}{r}821 \\
(73.2)\end{array}$ & $\begin{array}{c}301 \\
(26.8)\end{array}$ & $\begin{array}{r}1122 \\
(100.0)\end{array}$ & \\
\hline
\end{tabular}

Table 4 - Association among headache self-report, painful temporomandibular disorders (TMD) and sleep bruxism (SB).

\begin{tabular}{lcccc}
\multirow{4}{*}{ temporomandibular disorders (TMD) and sleep bruxism (SB). } & \multicolumn{3}{c}{ Headache Self-Report } & \\
\cline { 2 - 4 } & Absence & Presence & Total & \\
\cline { 2 - 4 } & $n$ & $n$ & $n$ & OR 95\% Cl \\
\hline - TMD - SB & 425 & $(\%)$ & $(\%)$ & Reference \\
& $(64.9)$ & $(35.1)$ & $(100.0)$ & \\
- TMD + SB & 112 & 69 & 181 & $1.1(0.81-1.60)$ \\
& $(61.9)$ & $(38.1)$ & $(100.0)$ & $\mathrm{p}=0.5096$ \\
+ TMD - SB & 51 & 115 & 166 & $4.2(2.89-6.01)$ \\
& $(30.7)$ & $(69.3)$ & $(100.0)$ & $p<0.0001$ \\
+ TMD + SB & 23 & 97 & 120 & $7.8(4.81-12.62)$ \\
& $(19.2)$ & $(80.8)$ & $(100.0)$ & $p<0.0001$ \\
\hline \multirow{2}{*}{ Total } & 611 & 511 & 1122 & \\
& $(54.5)$ & $(45.5)$ & $(100.0)$ & \\
\hline
\end{tabular}

increase the risk for headache self-report. The association between TMD and SB had significantly increased the risk for headache self-report $(\mathrm{OR}=7.8 ; 95 \% \mathrm{Cl}=4.81$ - 12.62), followed by painful TMD only $(\mathrm{OR}=4.2 ; 95 \% \mathrm{Cl}=2.89$ 6.01) (Table 4).

\section{DISCUSSION}

To the best of our knowledge, studies investigating the multiple associations among painful TMD, SB, and $\mathrm{HA}$ in a sample population of adolescents are missing. 
Since all those conditions are highly prevalent and present great impact on individuals' lives, our findings contribute to the current knowledge. Our study found association among these three entities.

The present study showed that SB patients presented a greater risk of painful TMD and it is suggested that when painful TMD remains over the course of time, there may be several mechanisms involved. The main mechanisms are peripheral and central sensitization. At the periphery, the sensitivity of nociceptors can be altered by various substances released after tissue injury or inflammation (post-exercise muscle soreness), and can modify the excitatory potential of pain receptors, facilitating neuronal transmission, featuring a peripheral sensitization. If the peripheral sensitization is continuous and it comes from deep structures, a central process is established. This source of ongoing pain could act in the perpetuation of TMD. ${ }^{(8)}$ Therefore, SB could be considered a risk factor for TMD.

An important result found was the increased odds for HA self-report notably in patients with painful TMD and SB. It can be suggested that since TMD has been deeply associated with HA3, SB could be a risk factor for TMD8 and this, in turn, a risk factor for headache self-report.

However, attention should be taken when interpreting the results because some limitations might be identified. The present study is a cross-sectional model and thus only provides a possible association and not a cause-andeffect relationship. Moreover, the HA was not diagnosed, but was based on adolescent's response. Future studies with an accurate diagnose using the international classification of headache society are highly recommended.
In conclusion, the present study shows that SB - painful TMD greatly increases the risk for adolescent's headache self-report. For this reason, it was strongly recommend interaction between neurologists and dentists when evaluating and managing adolescents suffering from facial pain and HA.

\section{REFERENCES}

1. Stovner LJ, Hagen K, Jensen R, Katsarava Z, Lipton R, Scher A, et al. The global burden of headache: a documentation of headache prevalence and disability worldwide. Cephalalgia. 2007; 27: 193-210.

2. Mild-Busch A, Boneberger A, Heinrich S, Thomas S, Kuhnlein A, Radon $K$, et al. Higher prevalence of psychopathological symptoms in adolescents with headache. A population-based cross-sectional study. Headache. 2010; 50:738-48.

3. LeResche L, Mancl LA, Drangsholt MT, Huang G, Von Korff M. Preditors of onset of facial pain and temporomandibular disorders in early adolescence. Pain. 2007;12: 269-78.

4. Arruda MA, Guidetti V, Galli F, Albuquerque RCAP, Bigal ME. Childhood periodic syndromes: a population-based study. Pediatr Neurol. 2010;43:420-24.

5. Dworkin SF, LeResche L. Research Diagnostic criteria for temporomandibular disorders: review, criteria, examinations and specifications, critique. J Craniomand Disord. 1992; 6:301-55.

6. Lavigne GJ, Rompré PH, Montplaisir JY. Sleep bruxism: validity of clinical research diagnostic criteria in a controlled polysomnographic study. J Dent Res. 1996; 75: 546-52.

7. American Academy of Sleep Medicine. Sleep Related Movement Disorders. In: Sateia MJ, ed. International classification of sleep disorders: diagnostic and coding manual. 2nd ed. Westchester, Illinois: American Academy of Sleep Medicine. 2005: 189-91.

8. Lund JP, Lavigne GJ, Dubner R, Sessle BJ. Orofacial Pain: From basic science to clinical management. São Paulo: Quintessence; 2002. 